\title{
UJI AKTIVITAS ANTIOKSIDAN BODY BUTTER EKSTRAK ETANOL KULIT BUAH NAGA MERAH DENGAN METODE DPPH
}

\section{Antioxidant Activity of Red Dragon Fruit Extract Body Butter Using DPPH Method}

\author{
Repining Tiyas Sawiji'* \\ Elisabeth Oriana Jawa \\ $\mathbf{L a}^{2}$ \\ *ISekolah Tinggi Farmasi \\ Mahaganesha, Denpasar, Bali, \\ Indonesia \\ 2Sekolah Tinggi Farmasi \\ Mahaganesha, Denpasar, Bali, \\ Indonesia \\ *email: \\ repiningtiyas@gmail.com
}

\begin{abstract}
Abstrak
Kulit buah naga merah (Hylocereus polyrhizus) banyak dianggap sebagai limbah oleh masyarakat. Padahal di dalam kulit buah naga merah mengandung senyawa flavonoid, betasianin, antosianin, dan vitamin $\mathrm{C}$ yang mempunyai aktivitas antioksidan, sehingga dapat menangkal radiasi bebas dan mencegah kerusakan sel. Antioksidan adalah molekul yang dapat menghambat oksidasi molekul lain. Antioksidan dapat melindungi kulit dari berbagai kerusakan sel akibat radikal bebas. Body butter merupakan sediaan farmasi di bidang kosmetik yang dapat diaplikasikan untuk merawat kesehatan kulit. Penelitian ini bertujuan untuk mengetahui \% aktivitas antioksidan dan nilai IC 50 dalam sediaan body butter ekstrak etanol kulit buah naga merah. Kulit buah naga merah diekstraksi terlebih dahulu menggunakan metode maserasi dengan pelarut etanol 96\%. Uji aktivitas antioksidan diukur menggunakan spektrofotometri UV-Vis. Hasil penelitian menunjukkan bahwa nilai \% aktivitas antioksidan formula I diperoleh nilai IC 50 sebesar $49,94 \mu \mathrm{g} / \mathrm{mL}$., pada formula II diperoleh nilai IC 50 sebesar $82,53 \mu \mathrm{g} / \mathrm{mL}$, dan pada formula III diperoleh nilai $I_{50}$ sebesar $101,72 \mu \mathrm{g} / \mathrm{mL}$. Dari hasil yang diperoleh formula body butter yang memiliki aktivitas terbesar yaitu formula I dengan nilai $I_{50} 49,94 \mu \mathrm{g} / \mathrm{mL}(\mathrm{AAI}=0,8)$. Aktivitas antioksidan dalam sediaan body butter ekstrak etanol kulit buah naga merah termasuk ke dalam antioksidan sedang.
\end{abstract}

Kata Kunci:

Ekstrak kulit buah naga merah

Body butter

Antioksidan

DPPH

\section{Keywords:}

Red dragon fruit extract

Body butter

Antioxidants

DPPH

\begin{abstract}
Red dragon fruit peels (Hylocereus polyrhizus) is considered important by the community. While the red dragon fruit peel contains flavonoids, betacyanin, anthocyanin, and vitamin $C$ which have antioxidant activity, so that it can ward off free radiation and prevent cell damage. Antioxidants are molecules that can prevent oxidation of other molecules. Antioxidants can protect the skin from various free radical cell damage. Body butter is a pharmaceutical preparation in the cosmetic field that can be used for skin health care. This study aims to determine the percentage of antioxidant activity and $I C_{50}$ values in the body butter ethanol extract of red dragon fruit peels. Red dragon fruit peels were extracted first using maceration method with $96 \%$ ethanol solvent. The antioxidant activity test was measured using UV-Vis spectrophotometry. The results showed that the antioxidant activity value of formula I obtained $I C_{50}$ values $(49,94 \mu \mathrm{g} / \mathrm{mL})$, formula II I $C_{50}$ values $(82.53 \mu \mathrm{g} / \mathrm{mL})$, and formula III IC 50 values $(I 0 I .72 \mu \mathrm{g} / \mathrm{mL}$ ). From the results obtained, the body butter formula which has the greatest activity is formula I $(A A I=0.8)$. Antioxidant activity in body butter preparations is included in the group of moderate antioxidants.
\end{abstract}

(C) year The Authors. Published by Institute for Research and Community Services Universitas Muhammadiyah Palangkaraya. This is Open Access article under the CC-BY-SA License (http://creativecommons.org/licenses/by-sa/4.0/). DOI: https://doi.org// 0.33084/jsm.vxix.xxx.

\section{PENDAHULUAN}

Bagi kulit tubuh, manfaat utama antioksidan adalah untuk melindungi dan mencegah kerusakan kulit akibat bahaya radikal bebas. Kerusakan yang terjadi pada kulit akan mengganggu penampilan maupun kesehatan kulit (Maysuhara, 2009). Sumber radikal bebas dapat berasal dari paparan sinar UV, bahan kimia, polusi, debu, dan juga asap. Radikal bebas juga dapat berasal dari metabolisme tubuh itu sendiri. Didalam tubuh, radikal bebas mampu merusak kesehatan kulit dan mengakibatkan kulit mengalami dehidrasi, penuaan dini, warna kulit tidak merata bahkan kanker kulit (Widyastuti, 2010; Winahyu et al, 2019). Untuk mencegah terjadinya kerusakan kulit dari radikal bebas diperlukan suatu senyawa yang disebut dengan antioksidan.

Antioksidan adalah suatu molekul atom yang dapat menghambat proses oksidasi molekul lain. Oksidasi merupakan pelepasan elektron atom hidrogen yang 
dapat menghasilkan radikal bebas. Peristiwa ini dapat menyebabkan terjadinya suatu reaksi berantai, sehingga sel tubuh yang sehat dapat dirusak dengan cara mendonorkan salah satu elektronnya kepada senyawa yang bersifat oksidan, sehingga mampu menghambat reaksi oksidasi. Antioksidan dapat berupa vitamin C, vitamin $A$, dan vitamin $E$, enzim atau zat mineral. Kandungan lainnya dapat diperoleh dari sayur, buah, bahkan oatmeal.

Kulit tanaman Hylocereus polyrhizus merupakan salah satu tanaman yang mengandung antioksidan alami. Kulitnya sering dianggap sebagai limbah, padahal di dalam kulit nya banyak mengandung flavonoid, alkaloid, betasianin, dan vitamin $C$ yang memiliki fungsi sebagai antioksidan. Hal ini sejalan dengan penelitian yang dilakukan oleh (Mahargyani, 20I8) menyatakan bahwa di dalam ekstrak etanol kulit buah naga merah (Hylocereus polyrhizus) mengandung senyawa aktif golongan alkaloid, saponin, flavonoid, terpenoid, dan steroid serta memiliki sifat antioksidan dengan nilai $\mathrm{IC}_{50}$ sebesar 0,583 $\mathrm{mg} / \mathrm{mL}$. Kulit Hylocereus polyrhizus memiliki aktivitas antioksidan yang lebih tinggi dibandingkan dengan daging buahnya. Hal ini juga diperkuat oleh penelitian (Nurliyana et al, 2010; Putri et al, 2015) menyatakan bahwa di dalam I mg/mL kulit buah naga merah mampu menghambat radikal bebas sebesar 83,48 $\pm 1,02 \%$, sedangkan pada daging buah naga hanya mampu menghambat $27,45 \pm 5,03 \%$.

Tambahan antioksidan untuk kulit tidak hanya lewat makanan yang memiliki kandungan antioksidan saja, tetapi perlu juga diberikan lewat perawatan kulit untuk mencegah terjadinya kulit yang rusak akibat radikal bebas. Perawatan kulit yang paling mudah dengan cara rutin memakai body butter yang banyak mengandung antioksidan untuk melindungi dan menutrisi kulit dari sumber radikal bebas. Body butter merupakan sediaan farmasi yang memiliki tekstur lebih kental mirip mentega, paling banyak mengandung minyak sehingga kemampuannya dalam menjaga kelembapan kulit lebih baik daripada sediaan lotion. Kandungan di dalam body butter biasanya adalah cocoa butter atau coconut butter yang cukup tinggi mengandung minyak lemak.

Berdasarkan uraian tersebut, peneliti tertarik untuk membuat sediaan kosmetik dalam bentuk sediaan body butter ekstrak etanol kulit buah naga merah karena kandungan antioksidannya yang tinggi. Uji aktivitas antioksidan menggunakan metode DPPH bertujuan untuk mengetahui persentase aktivitas antioksidan dan nilai $\mathrm{IC}_{50}$ dari sediaan body butter ekstrak etanol kulit buah naga merah (Hylocereus polyrhizus).

\section{METODOLOGI}

Jenis penelitian ini adalah eksperimental. Penelitian ini dilaksanakan pada bulan Mei sampai Juni 2020, di Laboratorium Farmasetika dan Teknologi Farmasi STF Mahaganesha. Sampel yang digunakan adalah kulit buah naga merah yang diambil di wilayah Tabanan-Bali.

\section{BAHAN}

Bahan yang digunakan dalam penelitian ini adalah sediaan body butter ekstrak etanol kulit buah naga merah, Etanol 96\%, dan kristal DPPH.

\section{ALAT}

Alat dalam penelitian ini meliputi beaker glass, neraca analitik, aluminium foil, corong, labu ukur, gelas ukur, vial, pipet (tetes, mikro, ukur), alat centrifuge, Spektrofotometri UV-Vis.

\section{CARA KERJA}

\section{Preparasi Sampel}

Sampel buah naga merah dipotong, pisahkan antara daging buah dengan kulit nya, selanjutnya kulitnya dicuci bersih kemudian ditiriskan. Keringkan kulit buah naga merah hingga didapat berat konstan, kemudian diblender hingga halus.

\section{Pembuatan Ekstrak}

Ditimbang 100 gram serbuk kulit buah naga ditambahkan ethanol $96 \%$ sebanyak $250 \mathrm{~mL}$, kemudian diekstraksi selama 72 jam, tempatkan pada botol coklat dan terlindung dari cahaya dengan sesekali dilakukan pengocokkan. Pelarut etanol $96 \%$ diganti setiap 24 jam dan diremaserasi kembali tujuannya agar penyarian 
dapat optimal. Penyaringan dilakukan menggunakan kertas saring, Hasil ekstraksi kemudian dievaporasi dengan rotary evaporator hingga didapat kan ekstrak kental.

\section{Formulasi Sediaan}

Tabel I. Rancangan formulasi body butter

\begin{tabular}{lccc}
\hline \multirow{2}{*}{ Bahan } & \multicolumn{3}{c}{ Formula } \\
\cline { 2 - 4 } & I (gr) & II (gr) & III (gr) \\
\hline Ekstrak Etanol Kulit & 0,5 & I & 2 \\
Buah Naga Merah & & & \\
& &
\end{tabular}

\begin{tabular}{lccc}
\hline Asam Stearat & 8 & 8 & 8 \\
\hline $\begin{array}{l}\text { Cetyl Stearyl } \\
\text { Alkohol }\end{array}$ & 4 & 4 & 4 \\
\hline Steareth-20 & 0,4 & 0,4 & 0,4 \\
\hline Tween 60 & $\mathrm{I}$ & 2 & 3 \\
\hline Span 60 & $\mathrm{I}$ & 2 & 3 \\
\hline Coconut oil & 20 & 20 & 20 \\
\hline Cyclomethicone & 2 & 2 & 2 \\
\hline Cocoa butter & $\mathrm{I} 0$ & $\mathrm{I} 0$ & $\mathrm{I} 0$ \\
\hline Olive oil & $\mathrm{I}$ & $\mathrm{I}$ & $\mathrm{I}$ \\
\hline Glycerin & 2 & 2 & 2 \\
\hline Nipasol & 0,2 & 0,2 & 0,2 \\
\hline Nipagin & 0,3 & 0,3 & 0,3 \\
\hline Parfum Greentea & $5 \mathrm{tts}$ & $5 \mathrm{tts}$ & $5 \mathrm{tts}$ \\
\hline Aquadest & $\mathrm{Adl} 00$ & $\mathrm{Adl00}$ & $\mathrm{Ad} \mathrm{I00}$ \\
& $\mathrm{mL}$ & $\mathrm{mL}$ & $\mathrm{mL}$ \\
\hline
\end{tabular}

Fase minyak dimasukkan kedalam beaker glass, dipanaskan dengan suhu maksimal $70^{\circ} \mathrm{C}$ hingga fase minyak larut. Panaskan juga fase air diatas waterbath dengan suhu yang sama (gunakan sedikit aquades). Setelah fase minyak melebur tambahkan segera olive oil, aduk hingga merata. Masukkan fase minyak dan fase air ke dalam mortir secara bersamaan kemudian aduk cepat sampai suhu campuran turun. Masukkan ekstrak etanol kulit buah naga merah (Hylocereus polyrhizus) dan tambahkan sisa aquades secara perlahan-lahan hingga $100 \mathrm{~mL}$ kemudian diaduk hingga terbentuk emulsi (massa kental), diakhiri dengan penambahan parfum greentea.

\section{Pembuatan Larutan DPPH 40 ppm}

Sebanyak $10 \mathrm{mg}$ kristal DPPH ditimbang, dilarutkan dalam $10 \mathrm{~mL}$ etanol $96 \%$ kemudian didapatkan konsentrasi DPPH 1000 ppm. Dilakukan pengenceran bertingkat, sebanyak $10 \mathrm{ml}$ larutan induk diambil kemudian dilarutkan kedalam $100 \mathrm{ml}$ etanol $96 \%$, didapatkan konsentrasi 100 Ppm. Selanjutnya dari konsentrasi 100 ppm diencerkan kembali, diambil $40 \mathrm{ml}$ kemudian dilarutkan ke dalam $100 \mathrm{ml}$ etanol $96 \%$ didapatkan konsentrasi DPPH 40 ppm. Larutan DPPH ditutup dengan aluminium foil dan harus selalu dibuat baru.

\section{Uji Aktivitas Antioksidan}

Aktivitas antioksidan tahapan pengujianya dengan cara membuat pengenceran body butter dari tiap-tiap formula menggunakan pelarut etanol $96 \%$. Variasi konsentrasi pengenceran yang dibuat yaitu 10 ppm, 20 ppm, 30 ppm, 40 ppm, 50 ppm, dan 70 ppm. Tujuan pembuatan konsentrasi ini adalah untuk mencari nilai dari $\mathrm{IC}_{50}$ dengan menggunakan persaman matematis regresi linier. Serapan linier dapat diberikan apabila dibuat konsentrasi standarnya paling sedikit lima rentang konsentrasi yang meningkat (Widyasanti et al, 2016). Masing-masing larutan konsentrasi body butter diambil 2 $\mathrm{mL}$ di masukkan ke dalam vial kemudian ditambahkan dengan 2 mL larutan DPPH 40 pPm lalu dikocok untuk mencampurkan larutan. Volume total akhir larutan sampel dalam vial adalah $4 \mathrm{~mL}$, sehingga larutan DPPH yang terukur adalah 20 ppm dan konsentrasi larutan uji yang terukur masing-masing menjadi $5,10,15,20,25$, dan 35 ppm. Selanjutnya $2 \mathrm{~mL}$ larutan etanol 96\% ditambahkan $2 \mathrm{~mL}$ larutan DPPH 40 Ppm sebagai blanko. Semua sampel diinkubasi pada suhu kamar $27^{\circ} \mathrm{C}$ selama 30 menit. Analisis aktivitas antioksidan body butter diukur nilai absorbansinya menggunakan alat spektrofotometer UV-Vis dengan panjang gelombang maksimum yang telah didapat sebelumnya, yaitu $520 \mathrm{~nm}$. Aktivitas penangkapan radikal DPPH (\%IC) dihitung berdasarkan rumus:

$$
\text { Aktivitas Antioksidan }=\frac{A O-A 1}{A O} \times 100 \%
$$

Diketahui :

AO : Absorbansi Sampel Kontrol Negatif

AI : Absorbansi Sampel Uji 
Data aktivitas antioksidan dianalisis kemudian dihitung nilai $I_{50}$ ditentukan berdasarkan persamaan regresi linier, $y=a+b x$, dimana $y$ adalah \% IC sedangkan $x$ adalah konsentrasi body butter.

Suatu senyawa dikatakan memiliki antioksidan "sangat kuat" jika memiliki nilai $I_{50}$ kurang dari 50 Ppm, antioksidan "kuat" apabila nilai $\mathrm{IC}_{50}$ antara 50 ppm - 100 PPm, antioksidan "sedang" apabila memiliki nilai $\mathrm{IC}_{50}$ antara 100 ppm - 150 ppm, dan antioksidan "lemah" apabila memiliki nilai IC 50 antara I5I ppm - 200 ppm tetapi masih dinyatakan memiliki potensi sebagai antioksidan walaupun lemah. Semakin tinggi aktivitas antioksidan nya maka semakin kecil nilai IC $_{50}$ (Sayuti, 2017).

Perhitungan Antioxidant Activity Index (AAI) diperoleh dengan rumus (Fadhli, 2019):

$$
\text { Nilai } A A I=\frac{\text { Konsentrasi DPPH }(\mu \mathrm{g} / \mathrm{mL})}{\operatorname{IC50}(\mu \mathrm{g} / \mathrm{mL})}
$$

\section{HASIL DAN PEMBAHASAN}

Body butter merupakan salah satu sediaan farmasi topikal (krim) berupa kosmetik yang penggunaannya bertujuan untuk menjaga kesehatan dan kelembapan kulit. Body butter mampu mencegah kulit mengalami dehidrasi karena mengandung minyak yang lebih tinggi dibandingkan dengan body lotion. Oleh karena itu, sediaan body butter sangat cocok digunakan di daerah tropis dan pada area kulit yang biasa mengalami dehidrasi seperti siku, tumit, dan lutut (Sayuti, 2017).

Pada penelitian ini, formulasi body butter dikombinasikan dengan ekstrak etanol kulit buah naga merah (Hylocereus polyrhizus) yang berpotensi sebagai antioksidan. Berdasarkan hasil penelitian (Winahyu et al, 2019) menunjukkan bahwa ekstrak kulit buah naga merah terbukti memiliki aktivitas antioksidan yang kuat dilihat dari nilai $I C_{50}$ sebesar 2,6949, sehingga dapat digunakan sebagai zat aktif antioksidan alami dalam sediaan topikal. Antioksidan diketahui mampu menangkal radikal bebas, maka dari itu dapat menambah nilai manfaat atau kegunaan sediaan body butter dengan adanya kombinasi antioksidan.

Aktivitas antioksidan dilakukan pengujian secara invitro menggunakan peredaman radikal bebas DPPH. DPPH adalah senyawa radikal bebas yang dapat bereaksi dengan senyawa yang dapat mendonorkan atom hidrogen, dan sering digunakan dalam pengujian aktivitas antioksidan suatu ekstrak bahan alam (Putri et al, 2015). Interaksi antara DPPH dengan antioksidan baik secara pendonoran atom hidrogen atau transfer elektron dapat menetralkan radikal bebas dari DPPH. Jika semua elektronnya menjadi berpasangan karena keberadaan DPPH hal ini dapat menyebabkan absorbansinya menurun sesuai jumlah elektron yang diambil dan terjadi perubahan warna larutan DPPH dari ungu menjadi kuning akibat keberadaan senyawa antioksidan (Sayuti, 2017).

Pada tiap vial larutan uji terdapat sebanyak $2 \mathrm{~mL}$ larutan DPPH 40 ppm dan 2 mL larutan konsentrasi uji, volume akhir larutan sampel dalam vial adalah $4 \mathrm{~mL}$ sehingga larutan DPPH yang terukur adalah 20 Ppm dan konsentasi larutan uji yang terukur masing-masing menjadi 5, 10, 15, 20, 25, dan 35 ppm.

Penentuan aktivitas antioksidan menggunakan metode DPPH sedangkan pengukuran aktivitas antioksidan menggunakan spektrofotometer UV-Vis dengan panjang gelombang $520 \mathrm{~nm}$. Berikut merupakan hasil pengukuran aktivitas antioksidan sediaan body butter ekstrak etanol kulit buah naga merah (Hylocereus polyrhizus) pada formula I, formula II, dan formula III ditunjukkan pada Tabel 2, Tabel 3, dan Tabel 4.

Tabel 2. Aktivitas antioksidan body butter formula I

\begin{tabular}{|c|c|c|c|}
\hline $\begin{array}{c}\text { Konsent } \\
\text { rasi } \\
(\mu \mathrm{g} / \mathrm{mL})\end{array}$ & $\begin{array}{c}\% \\
\text { pereda } \\
\text { man }\end{array}$ & $\begin{array}{l}\text { Persamaan } \\
(y=b x+a)\end{array}$ & $\begin{array}{c}\mathrm{IC} \\
(\mu g / \mathrm{m} \\
\mathrm{L})\end{array}$ \\
\hline Blanko & 0 & \multirow{3}{*}{$\begin{array}{c}y=0.9424 x+ \\
2.9319 \\
R^{2}=0.8968\end{array}$} & \multirow{3}{*}{49.94} \\
\hline 5 & 4,45 & & \\
\hline 15 & $\begin{array}{l}15,45 \\
18.85\end{array}$ & & \\
\hline
\end{tabular}




\begin{tabular}{ll}
\hline 20 & 21.73 \\
\hline 25 & 24.87 \\
\hline
\end{tabular}

Tabel 3. Aktivitas antioksidan body butter formula II

\begin{tabular}{|c|c|c|c|}
\hline $\begin{array}{l}\text { Konsentr } \\
\text { asi } \\
(\mu \mathrm{g} / \mathrm{mL})\end{array}$ & $\begin{array}{c}\% \\
\text { peredam } \\
\text { an }\end{array}$ & $\begin{array}{l}\text { Persamaan } \\
(y=b x+a)\end{array}$ & $\begin{array}{c}\mathrm{IC} \\
(\mu \mathrm{g} / \mathrm{m} \\
\mathrm{L})\end{array}$ \\
\hline Blanko & 0 & \multirow{6}{*}{$\begin{array}{c}y=0.5855 x+ \\
1.6776 \\
R^{2}=0.89\end{array}$} & \multirow{6}{*}{82.53} \\
\hline 5 & 2.63 & & \\
\hline 10 & 9.21 & & \\
\hline 15 & 12.17 & & \\
\hline 20 & 12.83 & & \\
\hline 25 & 15.46 & & \\
\hline
\end{tabular}

Tabel 4. Aktivitas antioksidan body butter formula III

\begin{tabular}{|c|c|c|c|}
\hline $\begin{array}{l}\text { Konsentr } \\
\text { asi } \\
(\mu \mathrm{g} / \mathrm{mL})\end{array}$ & $\begin{array}{c}\% \\
\text { peredam } \\
\text { an }\end{array}$ & $\begin{array}{l}\text { Persamaan } \\
(y=b x+a)\end{array}$ & $\begin{array}{c}\mathrm{IC} \\
(\mu \mathrm{g} / \mathrm{m} \\
\mathrm{L})\end{array}$ \\
\hline Blanko & 0 & \multirow{6}{*}{$\begin{array}{c}y=0.4036 x+ \\
8.9458 \\
R^{2}=0.8823\end{array}$} & \multirow{6}{*}{$\begin{array}{c}101.7 \\
2\end{array}$} \\
\hline 5 & 9.64 & & \\
\hline 10 & 14.46 & & \\
\hline 15 & 15.06 & & \\
\hline 20 & 17.77 & & \\
\hline 25 & 18.07 & & \\
\hline
\end{tabular}

Nilai $I_{50}$ dari sediaan body butter ekstrak etanol kulit buah naga merah (Hylocereus polyrhizus) didapat dari analisis regresi linier sederhana $y=b x+a$. Koefisien $y$ pada persamaan ini adalah \% peredaman $\left(\mathrm{IC}_{50}\right)$, sedangkan koefisien $x$ pada persamaan ini adalah konsentrasi dari sediaan body butter ekstrak etanol kulit buah naga merah (Hylocereus polyrhizus). Hubungan \% peredaman dan konsentrasi body butter ekstrak etanol kulit buah naga merah (Hylocereus polyrhizus) ditunjukkan pada Gambar I, Gambar 2, dan Gambar 3.
Kurva Persen Peredaman DPPH

Oleh Body Butter Formula I

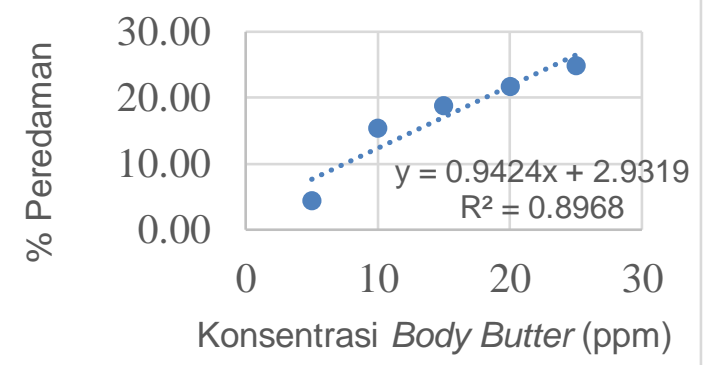

\section{Gambar I. Kurva persen peredaman DPPH formula I}

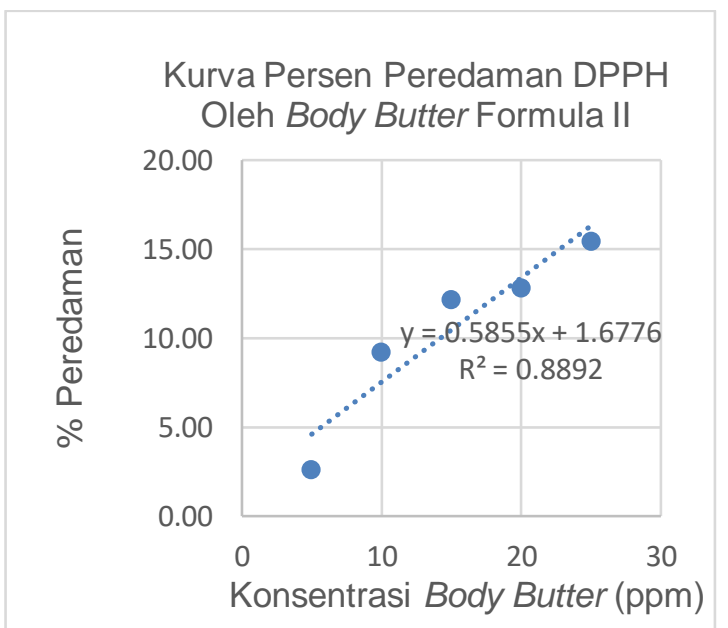

Gambar 2. Kurva persen perdaman DPPH formula II

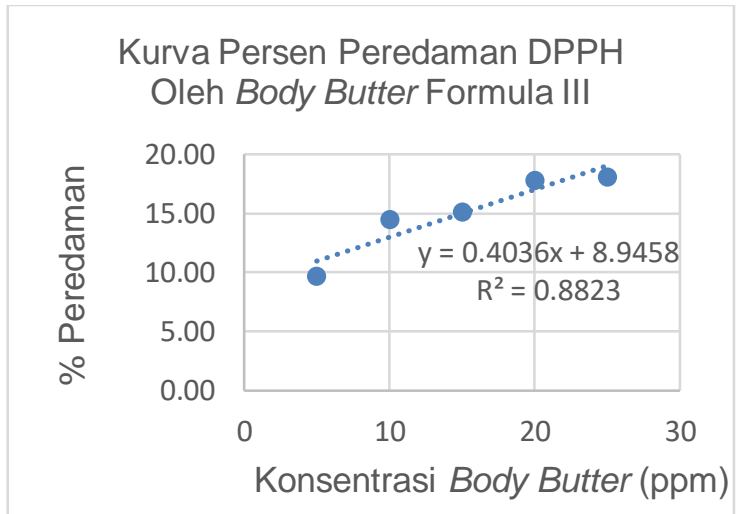

Gambar 3. Kurva persen peredaman DPPH formula III

Nilai $I_{50}$ atau inhibition concentration $50 \%$ merupakan konsentrasi efektif antioksidan yang dibutuhkan untuk meredam aktivitas radikal bebas (DPPH) sebanyak $50 \%$. Nilai $I_{50}$ merupakan parameter dari metode DPPH yang menunjukkan bahwa sediaan body butter mempunyai aktivitas antioksidan (Romdonah et al, 
2017). Semakin banyak aktivitas antioksidan maka nilai $\mathrm{IC}_{50}$ semakin kecil (Rahmatullah et al, 20I9). Antioxidant Activity Index (AAI) merupakan metode dalam menstandarisasi hasil pengujian antioksidan yang didasarkan metode DPPH. Nilai AAI berguna untuk penggolongan sifat antioksidan. Jika aktivitas antioksidan diperoleh nilai AAI kurang dari 0,05 artinya bersifat lemah. Jika aktivitas antioksidan diperoleh nilai AAI lebih dari atau sama dengan 0,05 artinya bersifat sedang. Jika nilai AAl antara I sampai 2 artinya bersifat kuat sedangkan apabila nilai AAI lebih dari 2 antioksidan sangat kuat (Vasic et al, 20I2).

Hasil uji aktivitas antioksidan body butter yang diperoleh formula I, II, dan III menunjukkan hasil yang berbedabeda, di mana semakin tinggi konsentrasi antioksidan di dalam body butter ekstrak etanol kulit buah naga (Hylocereus polyrhizus) semakin besar nilai $I_{50}$, dan semakin kecil nilai AAI yang diperoleh. Dari hasil yang diperoleh sediaan body butter ekstrak etanol kulit buah naga merah (Hylocereus polyrhizus) mampu menekan radikal bebas dalam tingkat sedang pada formula I $(A A l=0,8)$, formula II $(A A l=0,5)$, dan formula III $(\mathrm{AAl}=0,4)$. Hal ini disebabkan karena perbedaan konsentrasi ekstrak dan emulgator pada tiap formula serta bahan tambahan lain yang kemungkinan mampu menghambat aktivitas antioksidan dari ekstrak bahan alam, serta penyimpanan yang kurang baik seperti kontak dengan cahaya dan cara penyimpanan yang kurang baik (Rompis et al, 2019).

\section{KESIMPULAN}

Berdasarkan data yang diperoleh dari hasil penelitian dapat disimpulkan bahwa dalam sediaan body butter ekstrak etanol kulit buah naga merah (Hylocereus polyrhizus) mengandung antioksidan yang bersifat sedang.

\section{UCAPAN TERIMA KASIH}

Penulis mengucapkan terimakasih kepada Ketua Sekolah Tinggi Farmasi Mahaganesha dan Kepada LPPM Sekolah Tinggi Farmasi Mahaganesha

\section{REFERENSI}

I. Maysuhara, S. (2009). Rahasia Cantik, Sehat dan Awet Muda. Pustaka panasea.

2. Widyastuti. (20I0). Pengukuran Aktivitas Antioksidan dengan Metode Cuprac, Dpph, dan Frap serta Korelasinya dengan Fenol dan Flavonoid pada Enam Tanaman. Departemen Kimia Fakultas Matematika dan Ilmu Pengetahuan Alam, Institut Pertanian Bogor.

3. Winahyu, D.A., Purnama, R.C., dan Setiawati, M. Y. (2019). Uji Aktivitas Antioksidan Pada Ekstrak Kulit Buah Naga Merah (Hylocereus polyrhizus) Dengan Metode DPPH. Jurnal Analis Famasi, 4(2), I I7-I2I.

4. Mahargyani, W. (2018). Identifikasi Senyawa dan Uji Aktivitas Antioksidan Ekstrak Etanol Kulit Buah Naga Merah (Hylocereus polyrhizus). Prosiding Pertemuan Ilmiah Nasional Penelitian \& Pengabdian Masyarakat (PINLITAMAS I), I(I).

5. Nurliyana, R. Z.I. Syrd, S.K., Mustapa, M.R., Aisyah, R.K., Kamarul. (20I0). Antioxidant Study of Pulps and Peels of Dragon Fruits: A Comparative Study. International Food Research Journal, I 7, 367-375.

6. Putri, N.K, Gunawan, I.W.G, Suarsana, I.. (20I5). Aktivitas Antioksidan Antosianin dalam Ekstrak Etanol Kulit Buah Naga Merah Super Merah (Hylocereus costaricensis) dan Analisis Kadar Totalnya. Jurnal Kimia 9 (2), 243-25I.

7. Widyasanti, A., Rohdiana, D., Ekatama, N. (2016). Aktivitas Antioksidan Ekstrak Teh Putih (Camellia sinensis) dengan Metode DPPH (2,2 Difenil -IPikrilhidrazil). FORTECH, I(9).

8. Sayuti, N. (20I7). Uji Aktivitas Antiaging Invitro Lavender Body Butter. Jurnal Kebidanan Dan Kesehatan Tradisional, 2 (I), 30-37.

9. Romdonah, F.S., Kusumo, E., \& S. (2017). Identifikasi Betasianin dan Uji Antioksidan Ekstrak Kulit Buah Naga Merah (Hylocereus polyrhizus). Indonesian Journal of Chemical Science, 6 (I), I-4.

10. Rahmatullah, St., Permadi, Y.W., Utami, D. S. 
(2019). Formulasi Dan Uji Aktivitas Antioksidan Sediaan Hand And Body Lotion Ekstrak Kulit Nanas (Ananas comosus (L.) Merr) Dengan Metode DPPH. JF FIK UINAM, 7 (I).

II. Vasic, S.M., Stevanovic, O.D., Licina, B.Z., Radojavic, I.D., Comic, L. (20I2). Biological activities of extracts from cultivated Granadilla Passiflora alata. Excli Journal, I I: 208-2.

12. Rompis, F.F., Yamlean, Paulina V.Y., Lolo, W. A. (2019). Formulasi dan Uji Efektivitas Antioksidan Sediaan Masker Peel-Off Ekstrak Etanol Daun Sesewanua (Cleodendron squamatum Vahl.). PHFarmasi - UNSRAT, 8.

13. Fadhli, H. \& I. D. (2019). Uji Fitokimia Dan Potensi Antioksidan Dari Ekstrak Kulit Kayu Garunggang Cratoxylum arborecens (Vahl) Blume. Jurnal Farmasi Galenika, 6 (2), 68-79. 